\title{
Skill and knowledge requirements of entry-level logistics and supply chain management professionals: A comparative study of Ireland and Spain
}

\begin{abstract}
:
This study examines the educational and training requirements of entry-level graduates employed in the freight transport, distribution, and logistics sector. Five skill and knowledge categories are considered. By comparing the perceived importance of certain skills for companies and the performance of graduates, education and training gaps are identified. These gaps are compared for Ireland and Spain, two countries with different industrial and managerial contexts. Descriptive analysis of a sample of 108 firms reveals major gaps. The country comparison shows that Spanish graduates have more skill and knowledge deficiencies than Irish graduates. Despite the smaller gaps for Irish graduates, data variability is greater than for Spanish graduates.
\end{abstract}

Keywords: Supply chain management; logistics; skills and knowledge; graduate requirements; higher education institutions

Pre-printed version, cite this paper as:

Wagner, C., Sancho-Esper, F., \& Rodriguez-Sanchez, C. (2020). Skill and knowledge requirements of entry-level logistics and supply chain management professionals: A comparative study of Ireland and Spain. Journal of Education for Business, 95(1), 23-36.

DOI: https://doi.org/10.1080/08832323.2019.1596870 


\section{Introduction}

In today's business environment, competition occurs between supply chains rather than individual companies. Efficient and effective management of supply chain activities has become more complex and challenging because of the constantly changing structural characteristics of supply chains (Parker, Kent, \& Brown, 2001; Lorentz et al., 2013). This increase in complexity is caused by globalization of markets and production, expansion of product variety, shortening of product life cycles, continuous advances in information technology (IT), and a host of other factors (Kotabe et al., 2012). Within this context, there is growing awareness of the key role of people, knowledge, and talent in the success of logistics and supply chain management (SCM) activities (Mangan \& Christopher, 2005). There seems to be an ongoing global shortage of talented supply chain professionals with the necessary skills and business knowledge to manage increasingly complex global supply chain processes (Ellinger \& Ellinger, 2014).

The supply chain and logistics sector has witnessed a faster than average job growth rate, and there is a threat of a future shortage of skilled employees (Lutz \& Birou 2013; EGFSN, 2015). This potential shortage poses new challenges to educational institutions, which must deal with these skill gaps by developing suitable degree programs. The European Commission (2013) has suggested that higher education institutions (HEIs) should not only educate students in narrow knowledge-based specializations but also allow students to acquire a broader range of knowledge and skills. This situation is of particular concern in countries where the freight and logistics sector (FTDL) is of major strategic and operational importance. This is the case in Ireland and Spain, albeit for different reasons. The changing business environment in both countries calls for more robust approaches to analyze both logistics and SCM activities. Excellence in SCM is an important consideration for non-central European and international regions, which experience the natural disadvantage of a peripheral location with respect to significant markets and sources of raw materials. Accordingly, regions such as Ireland and Spain have longer and more complex transport chains as well as higher transport and distribution costs (Hummels, 2007).

The aim of this study is to identify entry-level logistics knowledge and skill requirements, their relative importance in different industries, and the perceived performance of graduates in Spain and Ireland, to provide insights into current skill and knowledge gaps in the SCM sector. The study evaluates which particular skillsets are in demand, which skillsets require improvement, and where SCM skill development priorities currently lie. This study contributes to the literature by providing a country comparison, which enables a better understanding of the skillsets that are typically required by international firms in different geographical and industrial settings.

\section{Literature review}

\subsection{Supply chain skill requirements}


Research indicates three critical elements for success in SCM: people, processes, and technology. These elements must be kept in harmony (Rahman \& Qing, 2014). At the same time, modern supply chain managers must understand the market and its dynamic business environment to define, measure, and manage each market segment (Christopher, 2004). The shift is toward a process-driven, valuecreating manager who not only has specific IT and functional expertise but can also manage crossfunctional teams both within and across organizations while considering costs, service and time-based performance indicators. Therefore, supply chain graduates must develop not only functional and management skills in logistics but also a network perspective. They must also become relationship managers (Farrell \& Wagner, 2014).

The business, logistics, and management (BLM) framework proposed by Poist (1984) is a pioneering framework for supply chain and logistics skills development. It draws on 80 skills and knowledge areas to define the skill requirements of both senior and entry-level logisticians. It suggests that logistics managers should be multiskilled generalists rather than technically oriented specialists (Murphy \& Poist, 1991). However, more recent studies have highlighted the need for production and information and communication management skills (Murphy \& Poist 2007) as well as teamwork, problem solving abilities, supply chain awareness, and the ability to see the "big picture” (Gammelgaard \& Larson, 2001). Sohal (2013) extended this list by adding technological skills, initiative and enterprise skills, as well as compliance and legal skills.

SCM implies a horizontal organizational orientation. Therefore, managers must have the appropriate skillsets to work in teams and across functions where different functional skills are combined with a common process focus (i.e., the “T-shaped” skill profile suggested by Mangan \& Christopher, 2005). In addition, a supply chain manager's skillset should include analytical, interpersonal, leadership, change management, and project management skills, with improvements needed in IT, finance, and operations (Prajogo \& Sohal, 2013). Given the huge changes taking place in the business environment, other areas such as management of multicultural environments (Rahman \& Qing, 2014; Dubey \& Gunasekaran, 2015), security (Hintsa et al., 2009; Voss \& Williams, 2013; Yang \& Wei, 2013), and sustainability (Lorentz et al., 2013; Sodhi \& Tang, 2018) have recently become important considerations in relation to the supply chain skillset.

In short, HEIs must focus on identifying graduates' skill gaps and on developing relevant supply chain curricula to improve the efficiency and effectiveness of future managers (Rahman \& Qing, 2014). Therefore, SCM skills should be perceived as inputs required by the labor market that are supplied by HEIs (Lorentz et al., 2013). A final concern relates to the actual achievement of professional competencies by young graduates. Skills and knowledge taught in class must be linked to actual contextdependent knowledge through organizational, on-the-job experience (Gammelgaard \& Larson, 2001). A 
further criticism of SCM education is that too much emphasis is placed on the technical aspects of the role to the detriment of other elements.

\subsection{Educational requirements}

The EU's 2020 Growth Strategy set four common objectives to address challenges in education and training systems. The strategy encompasses making lifelong learning and mobility a reality, improving the quality of education and training, promoting equity, social cohesion, active citizenship, and enhancing creativity and innovation, including entrepreneurship at all levels of education and training (European Commission, 2010). Academic learning, an objective of university education, includes the ability to recognize flaws in one’s knowledge base or competencies (Steur et al., 2012). Under lifelong learning, education is an ongoing process. It ensures that graduates continually learn and adapt beyond their formal education. However, Lutz and Birou (2013) have expressed concerns about recent graduates in terms of their readiness and availability. There is increasing pressure from higher education authorities to impart relevant knowledge in higher education to meet the labor-force requirements of today's economy (Hall et al., 2009).

In the case of SCM, educational research has progressed from a focus on curriculum content to a discussion about managerial skills and teaching methods (Lorentz et al., 2013). Other research has centered on the nature of the competencies and skills that graduates require to secure employment, with graduate employability attributes forming a key objective (Yorke, 2004). Graduate employability increasingly requires the demonstration of generic (i.e., across all subject areas) and subject-specific (i.e., based on a specific discipline or sector) competencies as well as critical and reflective thinking (Harvey et al., 1997). As an example, in job markets such as that of the UK, recruiters seem more interested in professional skills and general management knowledge than specific logistics and SCM subject knowledge (Wong et al., 2014). Moreover, work experience in the form of internships or consultancy projects becomes more important as the seniority of the graduate position increases. For instance, Sohal (2013) highlighted the value of collaboration between businesses, universities or colleges, and industry associations in developing the competencies of supply chain professionals. Thus, it is important that these skills and knowledge areas are identified and developed through university-industry partnerships (Connor \& Hirsch 2008; Wong et al., 2014).

The attributes of graduates of higher education in this context are skills, knowledge, and abilities that go beyond disciplinary knowledge and that are applicable to a range of situations. The stakeholders for whom the description of graduate attributes is particularly important are prospective students, the teams that develop and update curricula, potential employers, researchers, admissions staff of further study programs, and the professional agencies that accredit and endorse these programs. 


\subsection{SCM industry and related higher education in Ireland and Spain}

This section examines the features of the Irish and Spanish economies and its logistics SCM practices. This comparison is of interest because of the high relative importance of logistics and SCM in these two peripheral countries and the significant differences between them in terms of size, geography, and structural industry features. Thus, based on these similarities and differences, it is of interest to identify the common and specific skill and knowledge requirements in Ireland and Spain.

Ireland is a peripheral island country (see Figure 1) with 4.8 million inhabitants (CSO, 2017a). The logistics and SCM sector is key to the functioning and growth of its economy. Due to Ireland's cultural proximity to the US, use of the English language and EU membership, Ireland is home to numerous European headquarters of multinational corporations. Domestic limitations and the global orientation of Irish firms make the Irish economy highly reliant on multinational corporations and strategic global partnerships. Total Irish exports accounted for 117 billion Euros in 2016, the highest annual total on record (CSO, 2017b). Due to this global orientation, SCM and logistics is regarded as a critical business discipline in Ireland, with approximately 49,000 people directly employed in this sector (IEA, 2018). The forecast of available positions by 2020 is around 15,000. These positions are the result of expansion and replacement of existing jobs.

In parallel, there is increasing awareness of the critical role of people, knowledge, and talent in logistics and SCM success (Mangan \& Christopher, 2005). Surprisingly, specific higher education courses in logistics and/or SCM are scarce in Ireland (see Appendix A). At undergraduate level, only three out of 15 institutes of technology (20\%) and no university offered this type of program in the 2016/17 academic year. Similarly, dedicated postgraduate higher education in this specific area was offered by only $22 \%$ of institutions: four out of seven universities, two out of 15 institutes of technology, and one out of six recognized colleges (see Figure 1). These figures reveal 1) a lack of specific higher education geared toward the logistics and SCM sector in Ireland, despite its strategic importance, and 2) the fact that most of the available programs provide only full-time classroom-based education.

$<$ Insert Figure 1 about here $>$

Spain is a peninsular continental country (see Figure 1) with more than 46.5 million inhabitants (INE, 2017a), 10 times as many as Ireland. Like Ireland, Spain’s geographical location (i.e., a peripheral EU country) and idiosyncrasies mean that the Spanish logistics and SCM sector is an interesting target for geoeconomic analysis. Although fewer multinational corporations are located in Spain than in Ireland, Spain plays a key role in the links between Europe, Africa, and Latin America. As a result, the logistics and SCM sector in Spain is of growing importance to the Spanish economy, accounting for approximately 838,000 direct jobs (INE, 2017b) in 205,000 firms in 2012. This sector directly contributes to 
approximately 5\% of Spanish gross domestic product (GDP) and accounts for $6.4 \%$ of Spanish firms (CEOE, 2013).

Regarding specialized higher education, there is a large a number of courses in Spain compared to in Ireland, but such courses are less common if we look at the total population size (see Appendix A). At undergraduate level, only 12\% of public HEIs (6 out of 51) offer four-year bachelor's degrees, and these focus primarily on maritime transport. At postgraduate level, a wide variety of master's programs is offered by both public and private institutions (around 20\% of HEIs; see Appendix A). In total, 20 degrees are offered. Of these, five are offered by public universities, nine by private universities and business schools, and six by joint ventures between public and private institutions. Nine are online distancelearning programs.

This analysis reveals that in Ireland and Spain, both undergraduate education and postgraduate education in the logistics and SCM discipline area are becoming more important, reflecting the growth of this economic sector. However, the Spanish higher education system offers more variety in terms of programs, locations, and types of learning.

\section{Methodology}

Quantitative and qualitative data were gathered to measure potential gaps in the skills and knowledge requirements of entry-level logistics and SCM professionals in order to capitalize on their complementary nature when analyzing new, dynamic, complex concepts and issues (Golicic \& Davis, 2012).

\subsection{Participants and data collection}

Data were gathered using an email survey procedure. In Ireland, the link of the questionnaire was sent via email invitation to graduate employers linked to the Dublin Institute of Technology's Logistics and Supply Chain honors degree program as well as members of the Chartered Institute of Logistics \& Transport in Ireland (representing approximately 500 industry professionals). A total of 51 valid responses were received. In Spain, an email invitation was sent to firms belonging to national associations such as the Spanish Association of Transport \& Logistics Centers (ACTE), the Spanish Federation of Commodity Transportation (CETM), and the Association of Procurement, Contracting, and Procurement Professionals in Spain (AERCE). A total of 57 valid responses were received.

As mentioned earlier, the structure of the logistics and SCM industry in Ireland and Spain differs greatly because of the features of each country. Therefore, data for each country were gathered from a sample that was proportional to the national business population in each country in terms of firm size, location, and sector (see Table 1 for more detail). Such variances were expected because the sampling procedure was designed to gather a proportional sample of the firms in each of the two countries, which have structural differences in terms of their logistics industries. 
$<$ Insert Table 1 about here>

\subsection{Measures}

The questionnaire covered 59 skills. The questionnaire items (skills) were taken from an exhaustive review of the literature on the skills that an entry-level logistics and SCM professional should have today to perform normal activities in this sector. These items were categorized into five skillset areas based on the dimensions identified by Murphy and Poist's (1991) business, logistics, and management (BLM) framework. These items were complemented by more recent skills proposed by Yang and Wei (2013), Rahman and Qing (2014), Dubey and Gunasekaran (2015), and others (see Appendix B). These skillset areas are 1) generic skills (e.g., “knowledge of cultural differences” and “teamwork/team orientation”), 2) functional skills (e.g., “demand forecasting” and "benchmarking ability”), 3) analytical skills (e.g., “quantitative modeling skills” and "spreadsheet/Excel skills”), 4) environmental skills (e.g., “returned goods handling” and "knowledge of environmental issues”), and 5) security skills (e.g., "customs/trade partnership against terrorism” and “knowledge of container security initiatives”).

Respondents were first asked to rate the importance of each skill for their company and were then to rate the perceived performance of entry-level professionals in each skill. The scale for both questions ranged from 1 (very low importance/performance) to 7 (very high importance/performance). The aim was to identify gaps in graduate competencies. These gaps can be thought of as the difference between importance and performance for each skill area. This corresponds to the IPA approach suggested by Gunasekaran et al. (2004). The questionnaire also collected data on variables such as demographics, company-level information, and typical roles of supply chain graduates. The content validity of the measures was enhanced by pre-testing the questionnaire using comments from industry experts and academic colleagues.

Finally, to gain insight into the future of the logistics and SCM sector in both countries, 16 in-depth interviews were carried out in addition to the survey. This qualitative information was mainly used to identify any major changes to the business environment and to determine how these could affect skill requirements. Open questions such as "What are the usual functions of graduates in logistics, transport, and/or management of the value chain in your company?" "Have you observed any change in the business environment of your company?" and "What impact have these changes had on the skills required for workers in your sector?” were asked at this point.

\section{Results}

First of all, for all skill areas, initial exploratory factor analysis (EFA) was performed to analyze the structure of factors and to reduce the number of items for the descriptive analysis (see Appendix B). For example, for generic skills, the initial 21 items were reduced to 17 items. This retained $65 \%$ of total 
variance in three factors and had high internal consistency (Cronbach $\alpha=0.928$ ). Subsequently, the mean importance and performance for each skillset was calculated, and the gap analysis was performed in two stages. First, the overall skill gap for both countries together was assessed, and, second, the countries were then compared in terms of their skill gaps.

\subsection{Generic skills in the SCM sector}

Analysis of managers' perceptions of generic skills at entry level revealed substantial deficiencies. The overall analysis (Table 2a) revealed negative significant gaps in $47 \%$ of generic skills. Only four skills had positive gaps (i.e. knowledge of cultural differences $=0.35, \mathrm{p}<.01$; self-development skills $=$ 0.028, $\mathrm{p}<.01$; negotiation skills $=0.18, \mathrm{p}<.01$; and coordination skills $=.17, \mathrm{p}<.01$ ).

ANOVA tests were performed to compare these gaps based on firm size. Significant differences were observed for only four items: self-development, cross-functional coordination ability, time-management, and leadership skills. These findings suggest that managers perceive major deficiencies in graduates in terms of generic skills, regardless of firm size. The most important skills that companies expect are excellent problem solving abilities, critical thinking, people skills, teamwork orientation, leadership skills, and customer awareness orientation.

\section{<Insert Table 2 about here $>$}

A cross-country comparison between these generic skill gaps based on two population t-tests also revealed interesting differences (Table 2b). The country comparison shows that Irish respondents' perceptions of graduate workers' generic skills are better than those of Spanish managers. For example, Irish graduates outperform Spanish graduates in areas such as negotiating skills $(\mathrm{t}=7.17, \mathrm{p}<.01)$ and cross-functional coordination ability $(\mathrm{t}=5.64, \mathrm{p}<.01)$. Spanish graduates were better perceived for only one skill: stress management $(\mathrm{t}=-4.20, \mathrm{p}<.01)$.

\section{$<$ Insert Figure 2 about here $>$}

Overall, as it is shown in Figure 2, Irish graduates seem better prepared than Spanish graduates for the requirements of the SCM industry with their generic skills. This suggests that there is room for improvement of programs in Spanish HEIs.

\subsection{Functional skills in the SCM sector}

The overall analysis (Table 3a) of functional skills revealed poor performance in nine out of 17 items. The biggest gaps were, for example, in distribution requirement planning (gap $=-1.64, \mathrm{p}<.01$ ) and demand forecasting (gap $=-1.43, \mathrm{p}<.01$ ). Conversely, for $29 \%$ of the functional skills (five out of 17 ), graduates' performance exceeded the importance the firm attached to these skills [e.g., inventory management (gap $=1.01, \mathrm{p}<.01$ ) and material handling (gap $=0.63, \mathrm{p}<.05$ )]. ANOVA tests were 
performed to compare these gaps based on firm size. We found differences in skills such as: inventory management, material purchasing or order processing among others.

For the shake of completeness, in-depth interviews with selected survey participants were conducted to qualitatively assess the importance of functional activities and identify the typical roles of SCM and logistics graduates at entry level. Most respondents reported inventory management, forecasting, demand planning, operations support, and transport as key skills for recruitment.

\section{$<$ Insert Table 3 about here $>$}

The cross-country comparison revealed interesting differences between the two countries (Table 3b and Figure 3). The profile for Irish graduates seemed more unbalanced than the profile for Spanish graduates. Irish graduates were much better prepared than Spanish graduates in several functional skills. Examples were inventory management $(\mathrm{t}=8.29, \mathrm{p}<.01)$, purchasing $(\mathrm{t}=8.29, \mathrm{p}<.01)$, and supply chain costing skills $(\mathrm{t}=8.29, \mathrm{p}<.01)$. In a few areas, Irish graduates showed weaknesses [e.g., quality management $(\mathrm{t}=-3.54, \mathrm{p}<.01)$, distribution requirement planning $(\mathrm{t}=-3.47, \mathrm{p}<.01)$, and demand forecasting $(\mathrm{t}=-3.36, \mathrm{p}<.01)$ ]. In Spain, all gaps were negative. These negative gaps indicate a fundamental lack of functional skills for all items. Therefore, Spanish HEIs should promote functional skills and knowledge in their specialized degree programs.

\section{$<$ Insert Figure 3 about here $>$}

\subsection{Analytical skills in the SCM sector}

The analysis of analytical skills suggests also poor overall performance (see Table 4). The biggest deficiencies in analytical skills were observed in internal enterprise resource planning (ERP) integration, statistical skills, and ERP/EDI (electronic data interchange) integration skills. These negative differences imply that graduates will need to develop these skills after joining the company. This lack of skill was independent of firm size.

The results of the qualitative interviews indicate that the typical entry roles performed by graduates in this area are information management, data collection and analysis, process mapping and project planning for business transformation. Knowledge of key software (e.g., SAP, Oracle, and Microsoft Office) and barcode technology is very important. Big data knowledge and analysis abilities are crucial skillsets for the future.

\section{$<$ Insert Table 4 about here $>$}

There were minor differences between Irish and Spanish graduates regarding analytical skills (Table 4). Only general IT skills were more developed in Ireland than in Spain $(\mathrm{t}=3.69, \mathrm{p}<.01)$, whereas Spanish graduates had fewer deficiencies in terms of ERP integration $(\mathrm{t}=-2.78, \mathrm{p}<.01)$ and statistical 
skills $(\mathrm{t}=-2.50, \mathrm{p}<.0)$. As summarized in Figure 4, graduates in both countries should improve their knowledge and skills in relation to most analytical skills. This conclusion was also the most consistently repeated in the in-depth interviews.

$<$ Insert Figure 4 about here $>$

\subsection{Environmental and security skills in the SCM sector}

Recent events in the logistics and SCM sector such as regulatory changes and security issues have increased interest in analyzing these skill categories. The results reveal major differences (see Table 4). Only $40 \%$ of gaps related to environmental skills were negative and significant (ISO 14000 standards gap $=-0.22, \mathrm{p}<.05$; and knowledge of environmental issues gap $=-0.52, \mathrm{p}<.01$ ). Most security-related items had significant negative gaps and only for customs-trade partnership against terrorism (CTPAT) knowledge performance exceeded importance (gap $=0.52, \mathrm{p}<.01$ ). This lack of skill was independent of firm size (ANOVA tests). Data from in-depth interviews suggest that security and environmental roles within an organization are not typically performed by junior graduates. A certain level of seniority is required for these roles.

The cross-country comparison yielded interesting results (see Table 4b). Concerning environmental issues, skills such as reverse logistics $(\mathrm{t}=5.45, \mathrm{p}<.01)$ and salvage and scrap disposal $(\mathrm{t}=3.05, \mathrm{p}<.01)$ appear to be well developed in Ireland. In contrast, in the Spanish context, all items were poorly rated, with the exception of the knowledge of environmental issues $(t=-1.95, \mathrm{p}<.01)$. Finally, it seems that entry-level graduates are not sufficiently prepared to handle security issues because most gaps were negative in both countries. The only exception was Irish graduates' CTPAT knowledge $(\mathrm{t}=3.85, \mathrm{p}<.01)$. Overall, there seem to be major differences in managers' perceptions of environmental and security issues in the two countries. Graduates from Irish HEIs are better prepared in these skills and are better adapted to the requirements of these positions.

\subsection{Aggregate skills: Importance vs. performance analysis}

Skills were plotted on an importance-performance matrix (IPM) similar to the one used by Rahman and Qing (2014). The IPM was used to represent importance and performance measurements regarding the relative improvement priorities in the competitive environment (Lai \& Cheng, 2003). The IPM was a $2 \times 2$ plot (see Figure 5) with perceived importance of each skill (from low to high) on the x-axis and perceived performance of each skill (from low to high) on the y-axis.

This IPM grouped skills into four quadrants: low priority, overstatement, high priority, and excellence. The low priority quadrant contains skills that are both low importance and low performance. Skills included in this quadrant should be given low priority for improvement. In the overstatement quadrant, perceived skill importance is relatively low, but perceived performance is relatively high. This 
combination suggests that the HEI's resources have not been optimally allocated. The high priority quadrant contains skills with high perceived importance and low perceived performance. HEIs must pay attention to these skills in the future. The excellence quadrant shows that both the importance and the performance of skills are high, which suggests that HEIs are delivering services according to industry needs.

\section{$<$ Insert Figure 5 about here>}

The IPM for the Irish sample indicates that 13 skills from various categories (e.g., oral communication, cross-functional coordination ability, MRP knowledge, service management, and spreadsheet and Excel skills) lie in the low priority quadrant. In contrast, 11 skills (e.g., inventory and warehousing management, order processing, and salvage and scrap disposal) lie in the overstatement quadrant. This indicates that functional skills, in particular, are taught to a satisfactory level in Irish HEIs. The excellence quadrant comprises 15 skills (e.g., knowledge of cultural differences, comfort with change, people skills, and negotiating skills), most of which are generic. Finally, there are 11 high priority skills (e.g., transport management, demand forecasting and distribution requirement planning). These are mostly functional skills where improvement is required. The regression line on the IPM shows that, despite high graduates' performance in the excellence quadrant, performance scores for most skills are less than importance scores.

The IPM for the Spanish sample differs. Although graduates in Spain have more skill gaps overall, there seems to be a better matching of requirements in Spain than in Ireland. The IPM for Spain highlights 23 skills (e.g., inventory skills, warehouse management, and material handling) as low priority skills. Only one skill lies in the overstatement quadrant (statistical skills), whereas 29 skills lie in the excellence quadrant (e.g., conflict management, people skills, and negotiating skills). The sampled graduates scored relatively high in these skill areas, whereas results for the overall data reflect room for improvement. Finally, only four skills lie in the high priority quadrant (e.g., demand forecasting, distribution requirement planning, influencing skills and supply chain costing skills). Spanish HEIs seemingly do not adequately address these skills.

In conclusion, HEIs seem focused on teaching a set of skills and knowledge to prepare graduates to work in the logistics and SCM sector. However, they are also failing to address various skills that are considered important by companies. Spanish HEIs are institutions with degree programs that teach a more balanced curriculum. Irish HEIs tend to teach a more focused curriculum. The IPM highlights key areas for improvement in both countries.

\subsection{Major changes in the business environment}


Qualitative data collection in both countries highlighted four main areas for consideration: 1) end-toend business collaboration, 2) security and international business, 3) technology, innovation, and shorter product lifecycles, and 4) cost reduction and automation. The most common concern of supply chain and HR managers was the lack of suitable graduates in these areas. They stressed the poor offer of specific programs in both countries and reported that they recruit graduates from other disciplines such as business, science, engineering, and transport. They also forecast a large increase in the demand for graduates with the skills to deal with big data.

\section{Discussion and conclusions}

Research has identified the need to optimize SCM learning to sustain organizational competitive advantage (Goffnett et al., 2012). HEIs must not only educate students in narrow, knowledge-based specializations but also allow students to acquire a broad range of knowledge and skills (European Commission, 2013). This study examined five logistics and SCM knowledge and skills categories and identified skill gaps by comparing managers' perceptions of the skill importance and the skill performance of graduates in two countries: Spain and Ireland.

Our research showed that generic skills seem to be an important skill area in both countries. This finding is consistent with the proposed T-shaped skill profile, according to which successful SCM professionals need a broad understanding of related areas (Mangan \& Christopher, 2005). This finding corroborates the previously established belief that it is important to be a manager first and a logistician second (Kovács et al., 2012). Regarding skill gaps in this generic skills area, Irish firms report fewer significant skill gaps than Spanish firms. However, although there are more skill gaps in the Spanish sample, Spanish graduates seem to perform better than Irish graduates. Another trend arising from our results is the fact that functional skills are a key area for improvement in both countries; the Irish graduates profile appears to be more unbalanced than the Spanish profile. Irish graduates are better prepared in a narrower set of specific skills compared to Spanish graduates. Previous research has suggested that HEIs in logistics and SCM should provide more generalist and management-oriented knowledge and skills (Farrell \& Wagner, 2014; Rahman \& Qing, 2014). However, it is necessary not to overlook the specific functional skills required in this sector (e.g., materials handling, order processing or purchasing) as seems to be the case for Spain and Ireland according to our data. In the areas of analytical, environmental and security skills HEIs do not seem to meet industry requirements in both countries. Overall, it seems HEIs are teaching standard and, in some areas, old-fashioned programs that provide graduates with only some of the skills and knowledge that are currently on demand. As a result, there is room for developing new or redesigning existing programs based on the findings of the importanceperformance matrix (IPM) to ensure congruence between competencies, knowledge, and skills. 


\subsection{Implications and limitations}

This study makes three main contributions that relate to the development of new and existing SCM and logistics education programs. First, the literature review allows extending the pioneer BLM framework proposed by Poist (1984) to the new requirements owing to the changes in the SCM sector and to other countries with different inherent features. Second, the detailed analysis of skills and knowledge areas can help policymakers and education and training agencies to better design specific courses that enhance skill and knowledge development for the entire logistics and SCM workforce. Although more programs specializing in SCM education should be created in Spain to train students in both general and logistics-specific skills, in Ireland, it appears that education should be improved mainly in terms of the teaching of highly specific skills such as analytics and security. However, both countries have major gaps in the generic and functional skills that are necessary for employees of any company today, regardless of the sector (e.g., problem solving and stress management skills). Third, this study can also help firms' logistics and supply chain managers to identify the key skills and knowledge that graduates need to have, as well as any subsequent training needs and development of performance management programs. The results can also be useful to identify country-specific training needs. This implies that multinational companies that operate in different countries must adapt their workers' training programs to the appropriate country setting. Thus, internal training programs must be specific to each country to cover the skill gaps in that country.

This research has several limitations that should be noted. The sampling method was not random. A judgmental, nonrandom procedure was used to gather information from approximately 60 firms per country. This procedure was intended to proportionally represent the industry in each country. This limitation can be overcome by implementing more complex sampling methods and by enhancing the sample of firms. Presently, research is conducted to increase the sample size and to gather data from other countries such as Germany and Argentina. Despite its limitations, however, this study is an important first attempt to describe and understand the logistics and SCM sector in different national contexts and identify the skills required by industry and the actual performance of current graduate employees. This study is a starting point to develop and validate more precise measurements in future studies by, for example, using confirmatory factor analysis (CFA) to validate these measures and ensure good psychometric properties. It can also be of interest to use multifactor modeling to understand the underlying relationships between different skillsets and other relevant variables such as operational, sales, and profitability indicators.

\section{REFERENCES}

CEOE (2013). El sector del transporte y la logística en España. Consejo del Transporte y la Logística. Retrieved from: https://bit.ly/2CymLFM 
Christopher, M. (2004). Supply chains: a marketing perspective. In New S. and Westbrook R. (Eds.), Understanding Supply Chains, Oxford Univ. Press, NY/US, 23-42.

Connor, H. \& Hirsh, W. (2008). Influence through collaboration: Employer Demand for Higher Learning and Engagement with Higher Education, CIHE, London.

CSO (2017a). Census 2016 Summary Results - Part 1. Retrieved from: https://bit.ly/2nfQ1Lq

CSO (2017b). Goods export and imports 2016 (Irish Central Office of Statistics). Retrieved from: https://bit.ly/2LFvdWV

Dubey, R. \& Gunasekaran, A. (2015). Supply chain talent: the missing link in supply chain strategy. Industrial and Commercial Training, 47(5), 257-264

EGFSN (2015). Addressing the Demand for Skills in the Freight Transport, Distribution and Logistics Sector in Ireland 2015-2020. Retrieved from: https://bit.ly/2SkOxuT

Ellinger, A.E. \& Ellinger, A.D. (2014). Leveraging human resource development expertise to improve supply chain managers' skills and competencies. European Journal of Training and Development, 38(1/2), 118-135.

European Commission (2010). Strategic framework - Education \& Training 2020. Retrieved from: https://bit.ly/2mY6Vcu

European Commission (2013). Modernisation of higher education. Report, June 2013. Retrieved from: https://bit.ly/2uQCwlX

Farrell, M. \& Wagner, C. (2014). The role of work placement, its preparation and assessment in enhancing student learning and graduate employability: a case example of an undergraduate logistics and supply chain degree.” 6th International Conference on Education and New Learning Technologies, Barcelona, 7-9 July.

Gammelgaard, B. \& Larson, P.D. (2001). Logistics skills and competencies for supply chain management. Journal of Business Logistics, 22(2), 27-50.

Goffnett, S.P., Cook, R.L., Williams, Z. \& Gibson, B.J. (2012). Understanding satisfaction with supply chain management careers: An exploratory study. The International Journal of Logistics Management, 23(1), 135-158.

Golicic, S.L. \& Davis, D.F. (2012). Implementing mixed methods research in supply chain management. International Journal of Physical Distribution \& Logistics Management, 42(8/9), 726-741.

Gunasekaran, A., Patel, C. \& McGaughey, R.E. (2004). A framework for supply chain performance measurement. Internat. Journal of Production Economics, 87(3), 333-347.

Hall, M., Higson, H. \& Bullivant, N. (2009). The role of the undergraduate work placement in developing employment competences: results from a 5 year study of employers. DECOWE International Conference, 24-26. 
Harvey, L., Geall, V. \& Moon, S. (1997). Graduates' work: Implications of organizational change for the development of student attribute. Industry and Higher Education, 11(5), 287-296.

Hintsa, J., Gutierrez, X., Wieser, P., \& Hameri, A.P. (2009). Supply chain security management: an overview. Internat. Journal of Logistics Systems and Management, 5(3-4), 344-355.

Hummels, D. (2007). Transportation costs and international trade in the second era of globalization. Journal of Economic Perspectives, 21(3), 131-154.

IEA (2018). Freight Transport, Distribution and Logistics sector will need up to 15,500 extra skilled workers to 2020. Retrieved from: https://bit.ly/2rRqurQ

INE (2017a). Encuesta continua de hogares año 2017. Retrieved from: https://bit.ly/2rON2JU

INE (2017b). Estadística estructural de empresas: Sector servicios estadística de productos en el sector servicios Año 2015. Retrieved from: http://www.ine.es/prensa/eess_2015.pdf

Kotabe, M., Mol, M.J., Murray, J.Y. \& Parente, R. (2012). Outsourcing and its implications for market success: negative curvilinearity, firm resources, and competition. Journal of the Academy of Marketing Science, 40(2), 329-346.

Kovács, G., Tatham, P., \& Larson, P. D. (2012). What skills are needed to be a humanitarian logistician? Journal of Business Logistics, 33(3), 245-258.

Lai, K.H. \& Cheng, T.C.E. (2003). Supply chain performance in transport logistics: an assessment by service providers. International Journal of Logistics: Research and Applications, 6(3), 151-164.

Lorentz, H., Töyli, J., Solakivi, T. \& Ojala, L. (2013). Priorities and determinants for supply chain management skills development in manufacturing firms. Supply Chain Management: An International Journal, 18(4), 358-375.

Lutz, H. \& Birou, L. (2013). Logistics education: a look at the current state of the art and science". Supply Chain Management: An International Journal, 18(4), 455-467.

Mangan, J. \& Christopher, M. (2005). Management development and the supply chain manager of the future. The International Journal of Logistics Management, 16(2), pp.178-191.

Murphy, P.R, \& Poist, R.F. (2007). Skill requirements of senior - level logisticians: a longitudinal assessment. Supply Chain Management: An Int. Journal, 12(6), 423-431.

Murphy, P.R. \& Poist, R.F. (1991). A comparison of headhunter and practitioner views regarding skill requirements of senior-level logistics managers. Logistics and Transportation Review, 27(3), 277294.

Parker, R. S., Kent, J. L., \& Brown, T. S. (2001). The perceived importance of statistics in the logistics and transportation industry. Journal of Education for Business, 76(4), 185-188.

Poist, R.F. (1984). Managing logistics in an era of change. Defence Transportation Journal, September/October, 23-30. 
Prajogo, D. \& Sohal. A. (2013). Supply chain professionals: A study of competencies, use of technologies, and future challenges. International Journal of Operations \& Production Management, 33(11/12), 1532-1554.

Rahman, S. \& Qing, N. (2014). Graduate students' perceptions of supply chain skills for supply chain managers. Benchmarking: An International Journal, 21(2), 276-299.

Sauber, M., McSurely, H., \& Rao Tummala, V. (2008). Developing supply chain management program: a competency model. Quality assurance in Education, 16(4), 375-391.

Sodhi, M.S. \& Tang, C.S. (2018). Corporate social sustainability in supply chains: a thematic analysis of the literature. Int. Journal of Production Research, 56(1-2), 882-901.

Sohal, A.S. (2013). Developing competencies of supply chain professionals in Australia: collaboration between businesses, universities and industry associations. Supply Chain Management: An International Journal, 18(4), 429-439.

Steur, J.M., Jansen E.P.W.A. \& Hofman W.H.A. (2012). Graduateness: An empirical examination of the formative function of university education. Higher Education, 64, 861-874.

Voss, M.D. \& Williams, Z. (2013). Public - private partnerships and supply chain security: C - TPAT as an indicator of relational security. Journal of Business Logistics, 34(4), 320-334.

Wong, C.W., Grant, D.B., Allan, B. \& Jasiuvian, I. (2014). Logistics and supply chain education and jobs: a study of UK markets. The International Journal of Logistics Management, 25(3), 537-552.

Yang, C.C. \& Wei, H.H. (2013). The effect of supply chain security management on security performance in container shipping operations. Supply Chain Management: An International Journal, 18(1), 7485.

Yorke, M. (2004). Employability in Higher Education: What it is - What it is Not. Retrieved from: https://bit.ly/2SmxGYO 
Figure 1

SCM undergraduate and postgraduate higher education in Ireland and Spain

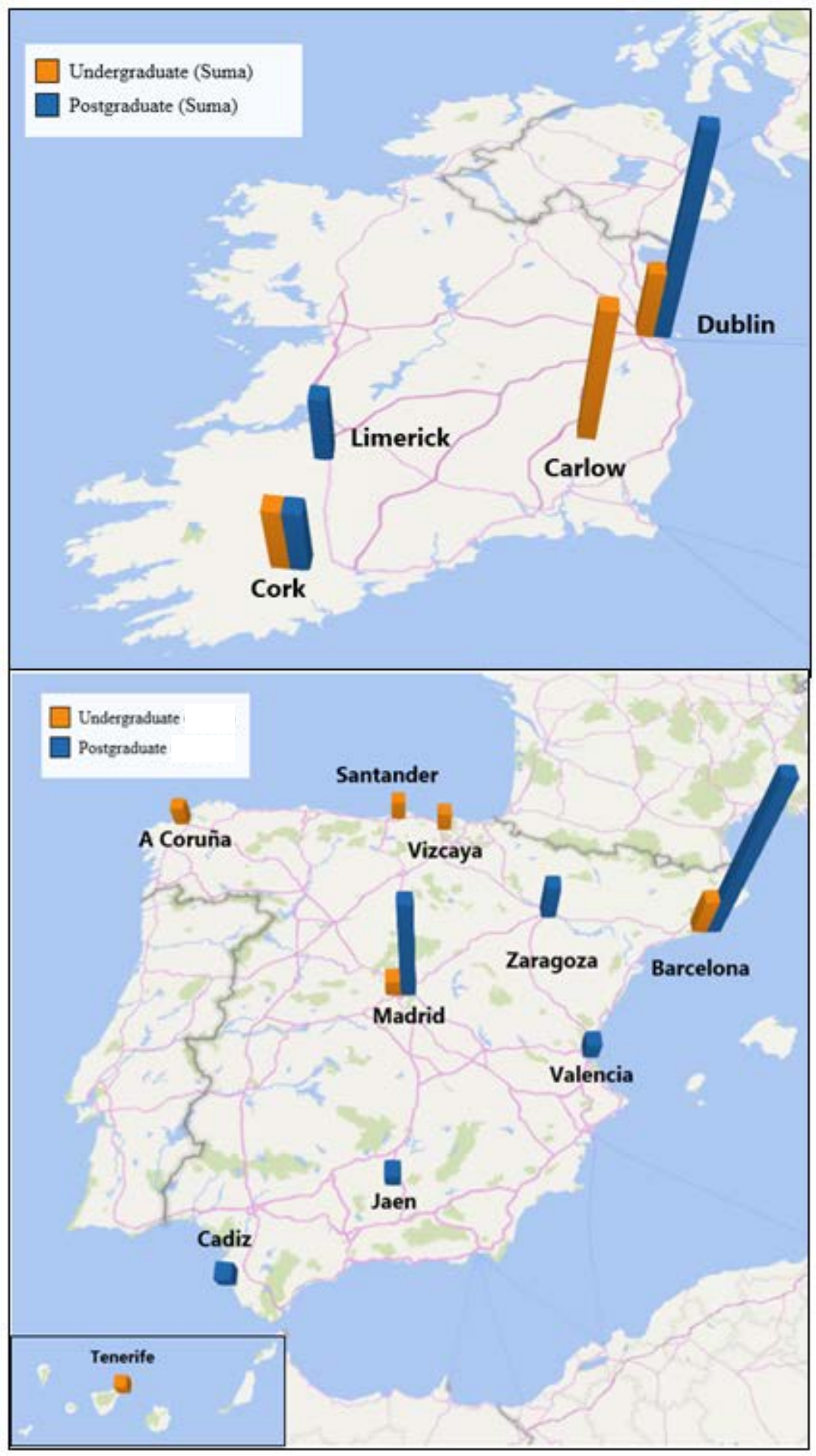


Figure 2.

Country comparison of generic skill gaps: Ireland vs. Spain

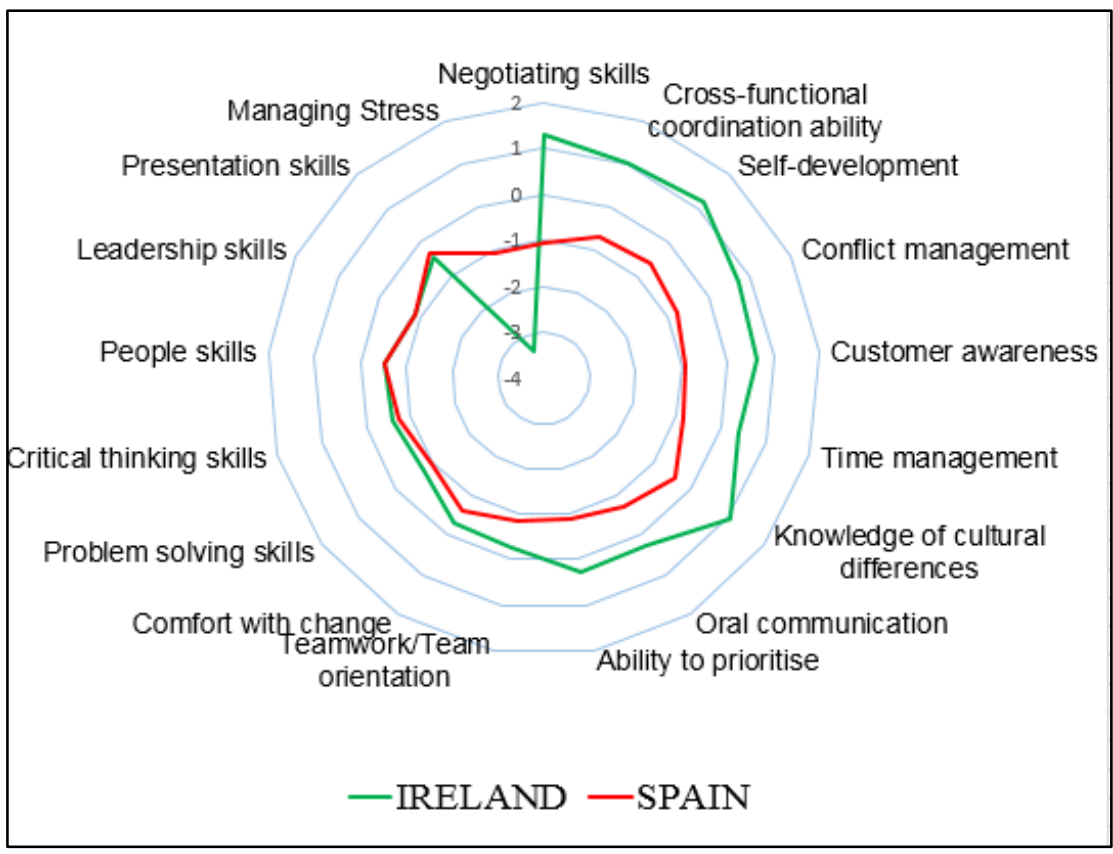

Figure 3.

Country comparison of functional skill gaps: Ireland vs. Spain

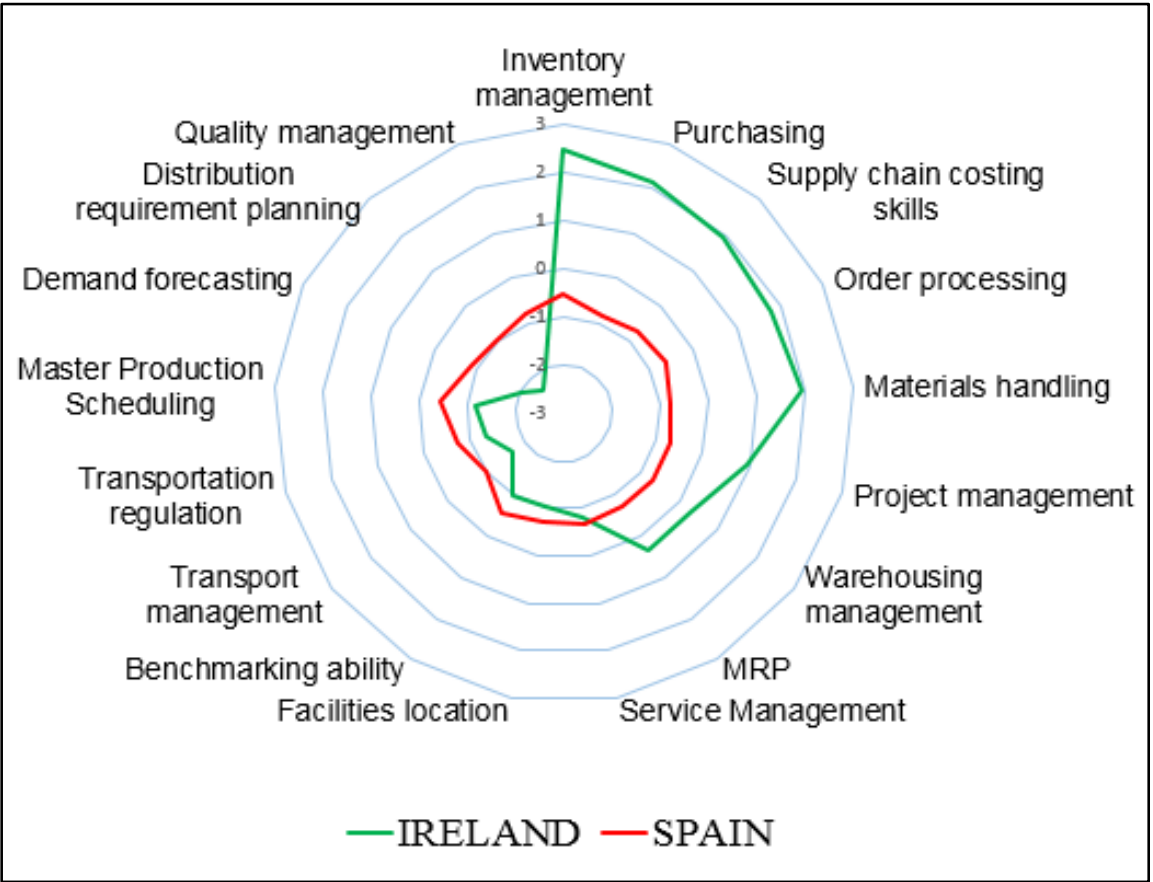


Figure 4.

Country comparison of analytical skill gaps: Ireland vs. Spain

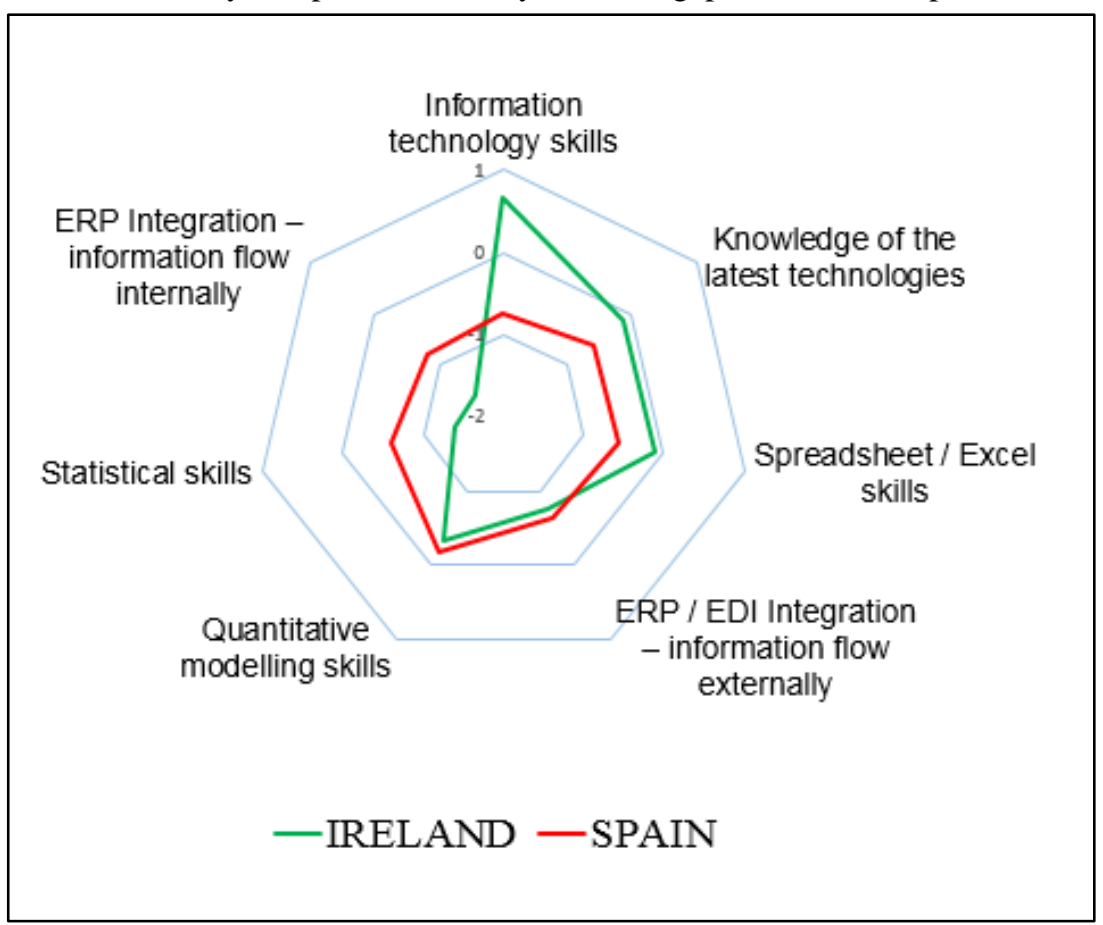


Table 1.

Characteristics of the sample: size, city/region, sector (firm) and educational level and work experience (respondent)

\begin{tabular}{lcc|lcc}
\hline \multicolumn{1}{c}{ Firm size* } & Ireland & Spain & \multicolumn{1}{c}{$\begin{array}{c}\text { Respondent } \\
\text { educational level }\end{array}$} & Ireland & Spain \\
\hline Large (>250) & $70 \%$ & $23 \%$ & Secondary education & $3 \%$ & $6 \%$ \\
Medium (50-250) & $15 \%$ & $25 \%$ & Professional certification & $8 \%$ & $34 \%$ \\
Small (10-50) & $9 \%$ & $26 \%$ & University degree & $31 \%$ & $40 \%$ \\
Micro (1-10) & $6 \%$ & $26 \%$ & Master (MA/MSc) & $58 \%$ & $20 \%$ \\
\hline Firm city/region & Ireland & \multicolumn{1}{c}{ Firm city/region } & Spain \\
\hline Dublin area & $60 \%$ & Madrid & $30 \%$ \\
County Cork & $20 \%$ & Barcelona & $22 \%$ \\
County Clare & $12 \%$ & Valencia & $16 \%$ \\
Kildare & $8 \%$ & Zaragoza & $8 \%$ \\
& & Alicante & $5 \%$ \\
\hline \multicolumn{1}{c}{ Sector } & Ireland & & \multicolumn{2}{c}{ Sector } & Spain \\
\hline Logistics/SCM & $27 \%$ & Logistics/SCM & $64 \%$ \\
Tech. Manufacture & $20 \%$ & Retail \& shoes & $12 \%$ \\
Food \& beverages & $14 \%$ & Food \& beverages & $4 \%$ \\
Pharma \& medical & $14 \%$ & Ceramics \& cements & $6 \%$ \\
Services & $7 \%$ & Metals & $4 \%$ \\
\hline
\end{tabular}

* In number of employees. 
Table 2. Generic Skills

Table 2a.

Table 2b.

Overall generic skills: importance, performance \& gap (full sample ${ }^{1}$ )

Country comparison of generic Skill gaps: Ireland ${ }^{1}$ vs. Spain ${ }^{1}$

\begin{tabular}{|c|c|c|c|c|c|c|c|c|c|c|}
\hline \multirow{2}{*}{ Generic Skill items } & \multirow{2}{*}{$\begin{array}{r}\text { IMPOR } \\
\text { Mean (SD) }\end{array}$} & \multirow{2}{*}{$\begin{array}{c}\text { PERF } \\
\text { Mean (SD) }\end{array}$} & \multirow{2}{*}{\begin{tabular}{|c} 
Skill gap \\
(diff. $^{2}$ )
\end{tabular}} & \multirow{2}{*}{$\begin{array}{c}\mathrm{F}^{*} \\
\left(\text { Firm size }^{3}\right)\end{array}$} & \multirow{2}{*}{ Generic Skill items } & \multicolumn{2}{|c|}{ IRELAND } & \multicolumn{2}{|c|}{ SPAIN } & \multirow{2}{*}{$\begin{array}{c}\mathrm{t}- \\
\text { statistic }\end{array}$} \\
\hline & & & & & & GAP & $(S D)$ & GAP & $(S D)$ & \\
\hline G1. Knowledge of cultural differences & $4.8(2.1)$ & $5.2(1.9)$ & $+0.35 * *$ & 0.44 & G7. Negotiating skills & 1.30 & (1.93) & -1.08 & $(1.45)$ & $+7.17 * *$ \\
\hline G16. Self-development & $4.4(1.9)$ & $4.7(1.7)$ & $+0.28 * *$ & $6.01^{* *}$ & G14. Cross-functional coordination ability & 1.02 & $(1.58)$ & -0.69 & $(1.49)$ & $+5.64 * *$ \\
\hline G7. Negotiating skills & $5.5(1.7)$ & $5.7(1.7)$ & $+0.18 * *$ & 0.86 & G16. Self-development & 1.16 & $(1.60)$ & -0.59 & $(1.63)$ & $+5.45^{* *}$ \\
\hline G14. Cross-functional coordination ability & $4.3(2.1)$ & $4.5(1.8)$ & $+0.17 * *$ & $3.78^{* *}$ & G4. Conflict management & 0.69 & $(1.45)$ & -0.78 & (1.36) & $+5.33 * *$ \\
\hline G4. Conflict management & $4.9(1.9)$ & $4.8(1.7)$ & -0.04 & 0.62 & G15. Customer awareness & 0.64 & $(1.71)$ & -0.92 & $(1.40)$ & $+5.15^{* *}$ \\
\hline G15. Customer awareness & $5.7(1.6)$ & $5.6(1.4)$ & -0.11 & 1.39 & G11. Time management & 0.39 & $(1.68)$ & -0.86 & $(1.33)$ & $+4.31 * *$ \\
\hline G11. Time management & $5.5(1.6)$ & $5.3(1.5)$ & -0.20 & $2.76^{*}$ & G1. Knowledge of cultural differences & 1.05 & $(2.28)$ & -0.43 & $(1.54)$ & $+4.00 * *$ \\
\hline G12. Oral communication & $4.5(2.0)$ & $4.3(1.8)$ & -0.23 & 0.68 & G12. Oral communication & 0.25 & $(1.22)$ & -0.73 & $(1.39)$ & $+3.79 * *$ \\
\hline G10. Ability to prioritize & $5.2(1.8)$ & $4.9(1.7)$ & -0.29 & 0.84 & G10. Ability to prioritize & 0.27 & (1.96) & -0.9 & $(1.50)$ & $+3.40 * *$ \\
\hline G20. Presentation skills & $4.8(1.6)$ & $4.4(1.8)$ & $-0.39 * *$ & 2.25 & G9. Teamwork/Team orientation & -0.26 & $(2.22)$ & -0.84 & $(1.41)$ & +1.64 \\
\hline G3. Comfort with change & $5.4(1.8)$ & $5.0(1.8)$ & $-0.45^{* *}$ & 0.22 & G3. Comfort with change & -0.29 & $(1.41)$ & -0.61 & $(1.25)$ & +1.25 \\
\hline G5. People skills & $5.9(1.4)$ & $5.4(1.6)$ & $-0.53^{* *}$ & 0.59 & G19. Problem solving skills & -0.71 & $(1.30)$ & -0.94 & $(1.43)$ & +0.86 \\
\hline G9. Teamwork/Team orientation & $5.9(1.5)$ & $5.4(1.5)$ & $-0.54 * *$ & 1.03 & G18. Critical thinking skills & -0.59 & (1.63) & -0.75 & $(1.53)$ & +0.5 \\
\hline G18. Critical thinking skills & $5.3(1.4)$ & $4.6(1.6)$ & $-0.66 * *$ & 0.30 & G5. People skills & -0.51 & $(1.45)$ & -0.55 & $(1.30)$ & +0.15 \\
\hline G19. Problem solving skills & $6.1(1.3)$ & $5.2(1.6)$ & $-0.82^{* *}$ & 0.61 & G17. Leadership skills & -0.89 & $(1.44)$ & -0.86 & $(1.37)$ & -0.11 \\
\hline G17. Leadership skills & $5.8(1.4)$ & $5.0(1.5)$ & $-0.87^{* *}$ & $3.03^{* *}$ & G20. Presentation skills & -0.44 & $(1.70)$ & -0.33 & $(1.31)$ & -0.36 \\
\hline G21. Managing Stress & $5.7(1.5)$ & $3.9(2.6)$ & $-1.74 * *$ & 2.46 & G21. Managing Stress & -3.39 & (3.09) & -1.10 & (1.43) & $-4.20 * *$ \\
\hline
\end{tabular}
$=57$

${ }^{2} \mathrm{t}$-test for paired populations (importance-performance) for each item.

${ }^{3}$ ANOVA test performed to compare the mean gap by firm size (European firm size classification)

${ }^{4}$ Independent sample $t$ test, considering a previous Levene test for variance equality is used.

${ }^{*} \mathrm{p}<0.05 ;{ }^{* *} \mathrm{p}<0.01$ 
Table 3. Functional Skills

Table 3a.

Table 3b.

Overall functional skills: importance, performance \& gap (full sample ${ }^{1}$ ) Country comparison of functional skill gaps: $\operatorname{Ireland}^{1}$ vs. Spain $^{1}$

\begin{tabular}{|c|c|c|c|c|c|c|c|c|c|c|}
\hline \multirow{2}{*}{ Functional Skill items } & \multirow{2}{*}{$\begin{array}{c}\text { IMPOR } \\
\text { Mean (SD) }\end{array}$} & \multirow{2}{*}{$\begin{array}{c}\text { PERF } \\
\text { Mean (SD) }\end{array}$} & \multirow{2}{*}{$\begin{array}{c}\text { Skill gap } \\
\text { (diff. }^{2} \text { ) }\end{array}$} & \multirow{2}{*}{$\begin{array}{l}\text { F-statistic } \\
\left(\text { Firm size }{ }^{3}\right)\end{array}$} & \multirow{2}{*}{ Functional Skill items } & \multicolumn{2}{|c|}{ IRELAND } & \multicolumn{2}{|c|}{ SPAIN } & \multirow{2}{*}{$\begin{array}{c}\mathrm{t}- \\
\text { statistic }\end{array}$} \\
\hline & & & & & & GAP & $(S D)$ & GAP & $(S D)$ & \\
\hline F2. Inventory management & $4.0(2.2)$ & $5.0(2.0)$ & $+1.01 * *$ & $6.66 * *$ & F1. Inventory management & 2.5 & (2.1) & -0.6 & $(1.5)$ & $+8.29 * *$ \\
\hline F10. Materials handling & $3.9(2.2)$ & $4.6(2.2)$ & $+0.63^{*}$ & $7.03^{* *}$ & F8. Purchasing & 2.1 & (2.3) & -0.8 & $(1.5)$ & $+7.66^{* *}$ \\
\hline F6. Order processing & $4.5(2.2)$ & $5.1(1.8)$ & $+0.61^{* *}$ & $2.92 *$ & F14. Supply chain costing skills & 1.9 & (2.4) & -0.7 & $(1.2)$ & $+7.13^{* *}$ \\
\hline F8. Purchasing & $4.1(2.3)$ & $4.7(2.3)$ & $+0.61^{* *}$ & $3.06^{* *}$ & F6. Order processing & 1.8 & $(2.2)$ & -0.6 & (1.1) & $+7.00^{* *}$ \\
\hline F14. Supply chain costing skills & $4.3(2.2)$ & $4.9(2.0)$ & $+0.60^{* *}$ & $9.25^{* *}$ & F10. Materials handling & 1.9 & $(2.2)$ & -0.8 & (1.6) & $+6.99 * *$ \\
\hline F12. Project management & $4.4(2.1)$ & $4.5(2.2)$ & +0.12 & $6.55^{* *}$ & F12. Project management & 0.9 & (2.5) & -0.7 & (1.4) & $+4.09 * *$ \\
\hline F4. Warehousing management & $4.3(2.2)$ & $4.2(2.1)$ & -0.11 & 0.84 & F4. Warehousing management & 0.4 & (2.1) & -0.7 & (1.3) & $+2.95 * *$ \\
\hline F17. MRP & $3.9(2.5)$ & $3.8(2.1)$ & -0.16 & 1.40 & F17. MRP & 0.4 & $(2.6)$ & -0.7 & $(1.4)$ & $+2.54 * *$ \\
\hline F19. Service Management & $4.9(2.1)$ & $4.2(1.9)$ & $-0.74 * *$ & 0.18 & F19. Service Management & -0.8 & $(2.4)$ & -0.7 & $(1.0)$ & -0.31 \\
\hline F13. Benchmarking ability & $4.5(2.2)$ & $3.7(2.1)$ & $-0.80^{* *}$ & 0.24 & F9. Facilities location & -1.0 & (2.5) & -0.7 & (1.5) & -0.77 \\
\hline F11. Master Production Scheduling & $4.3(2.4)$ & $3.5(2.2)$ & $-0.85 * *$ & 0.41 & F13. Benchmarking ability & -1.0 & (2.4) & -0.6 & (1.1) & -1.21 \\
\hline F9. Facilities location & $4.9(2.1)$ & $4.0(2.1)$ & $-0.90 * *$ & 0.30 & F1. Transport management & -1.7 & $(2.8)$ & -1.0 & $(1.7)$ & -1.47 \\
\hline F7. Transportation regulation & $5.4(1.9)$ & $4.4(1.9)$ & $-1.05 * *$ & 0.53 & F7. Transportation regulation & -1.3 & $(2.5)$ & -0.7 & $(1.4)$ & -1.51 \\
\hline F1. Transport management & $5.4(1.8)$ & $4.1(2.0)$ & $-1.27 * *$ & 0.10 & F11. Master Production Scheduling & -1.2 & $(2.1)$ & -0.5 & (1.4) & -1.98 \\
\hline F15. Quality management & $5.5(1.7)$ & $4.1(2.0)$ & $-1.32 * *$ & 0.73 & F3. Demand forecasting & -2.0 & $(2.0)$ & -0.8 & (1.5) & $-3.36^{* *}$ \\
\hline F3. Demand forecasting & $5.6(1.7)$ & $4.2(1.9)$ & $-1.43^{* *}$ & 0.64 & F5. Distribution requirement planning & -2.4 & (2.4) & -0.9 & (1.8) & $-3.47 * *$ \\
\hline F5. Distribution requirement planning & $5.5(2.0)$ & $3.8(2.1)$ & $-1.64 * *$ & 2.47 & F15. Quality management & -2.0 & $(2.2)$ & -0.8 & (1.0) & $-3.54 * *$ \\
\hline
\end{tabular}

${ }^{1}$ Full sample of firms: $\mathrm{n}_{\text {TOTA }} \mathrm{L}=108, \mathrm{n}_{\text {IRELAND }}=51$ and $\mathrm{n}_{\text {SPAIV }}=57$

${ }^{2} \mathrm{t}$-test for paired populations (importance-performance) for each item.

${ }^{3}$ ANOVA test performed to compare the mean gap by firm size (European firm size classification)

${ }^{4}$ Independent sample $t$ test, considering a previous Levene test for variance equality is used.

${ }^{*} \mathrm{p}<0.05 ;{ }^{* *} \mathrm{p}<0.01$ 
Table 4. Analytical, environmental and security skills

Table 4a.

Overall analytical, environmental and security skills (full sample ${ }^{1}$ )

Table 4b.

Country comparison of analytical, environmental and security skill gaps

\begin{tabular}{|c|c|c|c|c|c|c|c|c|c|c|}
\hline \multirow{2}{*}{ Skill items } & \multirow{2}{*}{$\begin{array}{c}\text { IMPOR } \\
\text { Mean (SD) }\end{array}$} & \multirow{2}{*}{$\begin{array}{c}\text { PERF } \\
\text { Mean (SD) }\end{array}$} & \multirow{2}{*}{$\begin{array}{l}\text { Skill gap } \\
\text { (diff. }^{2} \text { ) }\end{array}$} & \multirow{2}{*}{$\begin{array}{c}\text { F-statistic } \\
\left(\text { Firm size }^{3}\right)\end{array}$} & \multirow{2}{*}{ Skill items } & \multicolumn{2}{|c|}{ IRELAND $^{1}$} & \multicolumn{2}{|c|}{ SPAIN $^{1}$} & \multirow{2}{*}{$\begin{array}{c}\mathrm{t}- \\
\text { statistic }^{4}\end{array}$} \\
\hline & & & & & & GAP & $(S D)$ & GAP & $(S D)$ & \\
\hline \multicolumn{5}{|c|}{ ANALYTICAL SKILLS } & \multicolumn{6}{|c|}{ ANALYTICAL SKILLS } \\
\hline A3. Information technology skills & $5.3(1.9)$ & $5.3(1.8)$ & -0.02 & 1.10 & A3. Information technology skills & 0.7 & (2.5) & -0.8 & (1.3) & $+3.69 * *$ \\
\hline A2. Quantitative modelling skills & $4.5(2.1)$ & $4.2(1.9)$ & $-0.25 *$ & 0.99 & A1. Knowledge of the latest technologies & -0.1 & $(2.0)$ & -0.6 & $(1.0)$ & 1.61 \\
\hline A4. Spreadsheet / Excel skills & $4.7(2.1)$ & $4.3(2.0)$ & -0.34 & 0.10 & A4. Spreadsheet / Excel skills & -0.1 & (2.3) & -0.6 & (1.4) & 1.22 \\
\hline A1. Knowledge of the latest technologies & $5.7(1.4)$ & $5.4(1.6)$ & $-0.36^{*}$ & 0.57 & A8. ERP / EDI Integration - Info. flow externally & -0.8 & $(1.6)$ & -0.7 & (1.6) & -0.36 \\
\hline A8. ERP / EDI Integration - Info. flow externally & $4.9(2.0)$ & $4.2(2.1)$ & $-0.69 * *$ & 0.45 & A2. Quantitative modelling skills & -0.3 & (1.3) & -0.2 & $(1.0)$ & -0.74 \\
\hline A6. Statistical skills & $4.9(1.7)$ & $3.9(1.9)$ & $-0.99 * *$ & $2,83^{*}$ & A6. Statistical skills & -1.4 & $(1.6)$ & -0.6 & $(1.6)$ & $-2.50^{* *}$ \\
\hline A7. ERP Integration - Info. flow internally & $5.9(1.7)$ & $4.7(1.9)$ & $-1.21^{* *}$ & 0.30 & A7. ERP Integration - Info. flow internally & -1.6 & $(1.7)$ & -0.8 & $(1.1)$ & $-2.78 * *$ \\
\hline \multicolumn{5}{|c|}{ ENVIRONMENTAL SKILLS } & \multicolumn{6}{|c|}{ ENVIRONMENTAL SKILLS } \\
\hline E4. Reverse logistics & $3.5(2.5)$ & $3.7(2.0)$ & 0.19 & 1.14 & E4. Reverse logistics & 1.1 & $(1.7)$ & -0.7 & (1.5) & $+5.45^{* *}$ \\
\hline E3. Salvage and scrap disposal & $4.0(2.6)$ & $4.2(2.2)$ & 0.15 & 1.00 & E3. Salvage and scrap disposal & 0.6 & $(2.2)$ & -0.4 & (1.2) & $+3.05^{* *}$ \\
\hline E1. Return goods handling & $4.3(2.4)$ & $4.1(2.1)$ & -0.21 & 1.30 & E1. Return goods handling & 0.0 & (1.4) & -0.5 & (1.4) & $+1.80 * *$ \\
\hline E2. ISO 14000 Standards & $3.6(2.4)$ & $3.4(2.0)$ & $-0.22 *$ & 1.54 & E2. ISO 14000 Standards & 0.0 & (1.7) & -0.4 & (1.3) & 1.41 \\
\hline E5. Knowledge of environmental issues & $4.2(2.5)$ & $3.7(2.7)$ & $-0.52 * *$ & 1.64 & E5. Knowledge of environmental issues & -2.3 & $(3.0)$ & -0.5 & $(1.6)$ & $-1.95 * *$ \\
\hline \multicolumn{5}{|c|}{ SECURITY SKILLS } & \multicolumn{6}{|c|}{ SECURITY SKILLS } \\
\hline S2. CTPAT knowledge & $2.7(2.3)$ & $3.2(2.4)$ & $+0.52^{* *}$ & 0.57 & S2. CTPAT knowledge & 1.1 & $(2.1)$ & -0.2 & (1.3) & $+3.85^{* *}$ \\
\hline S4. 24h Manifest Rules knowledge & $2.9(2.5)$ & $2.8(2.7)$ & $-0.03 *$ & 2.12 & S4. 24h Manifest Rules knowledge & -0.8 & (3.4) & -0.4 & (1.1) & -0.41 \\
\hline S3. Container Security Initiatives (CSI) knowledge & $3.8(2.6)$ & $2.9(2.3)$ & $-0.95^{* *}$ & 1.45 & S3. Container Security Initiatives (CSI) knowledge & -1.2 & $(2.3)$ & -0.5 & (1.1) & $-2.03 * *$ \\
\hline S1. Customs and Trade Partnership against Terrorism & $4.2(2.6)$ & $2.8(2.2)$ & $-1.42 *$ & 1.97 & S1. Customs and Trade Partnership against Terrorism & -2.1 & $(2.6)$ & -0.7 & $(1.2)$ & $-3.34 * *$ \\
\hline
\end{tabular}

${ }^{1}$ Full sample of firms: $\mathrm{n}_{\text {TOTA }} \mathrm{L}=108, \mathrm{n}_{\text {IRELAND }}=51$ and $\mathrm{n}_{\text {SPAIN }}=57$

${ }^{2}$ t-test for paired populations (importance-performance) for each item.

${ }^{3}$ ANOVA test performed to compare the mean gap by firm size (European firm size classification)

${ }^{4}$ Independent sample $t$ test, considering a previous Levene test for variance equality is used.

${ }^{*} \mathrm{p}<0.05 ;{ }^{* *} \mathrm{p}<0.01$ 
APPENDIX A.

Third-level courses in Transport \& SCM in Ireland and Spain, 2016-2017 academic year

\begin{tabular}{|c|c|c|c|}
\hline \multirow{14}{*}{$\begin{array}{c}\text { Undergraduate } \\
\text { level }\end{array}$} & Program & Institution & Location \\
\hline & \multicolumn{3}{|c|}{ IRELAND } \\
\hline & BSc in Business in Supply Chain \& Transport Management & Cork IT & Cork \\
\hline & BSc (Hon) in Logistics \& Supply Chain Management & Dublin IT & Dublin \\
\hline & BSc (Hon) in Supply Chain Management & IT Carlow & Carlow \\
\hline & Higher Diploma in Business in Supply Chain Management & IT Carlow & Carlow \\
\hline & \multicolumn{3}{|c|}{ SPAIN } \\
\hline & BSc in Maritime Logistics \& Business & Pompeu Fabra University & Barcelona \\
\hline & BSc in Transport \& Logistic Science & Universidad Camilo José Cela & Madrid \\
\hline & BSc in Maritime Transport \& Sea Navigation & Universidad de la Coruña & A Coruña \\
\hline & BSc in Maritime Transport \& Nautical Engineering & Universidad de las Palmas & Tenerife \\
\hline & BSc in Maritime Transport \& Nautical Engineering & Universidad de Cantabria & Santander \\
\hline & BSc in Maritime Transport \& Sea Navigation & Universidad País Vasco & Vizcaya \\
\hline & BSc in Maritime Transport \& Navigation & Universidad Politécnica Catalunya & Barcelona \\
\hline \multirow{30}{*}{$\begin{array}{c}\text { Postgraduate } \\
\text { level }\end{array}$} & Program & Institution & Location \\
\hline & \multicolumn{3}{|c|}{ IRELAND } \\
\hline & MSc in Supply Chain Management & Dublin IT & Dublin \\
\hline & MSc in International Procurement \& Supply Management & Griffith College & Dublin \\
\hline & Master of Science in Supply Chain Management & IT Carlow & Carlow \\
\hline & MSc in Operations and Supply Chain Management & Trinity College Dublin & Dublin \\
\hline & MSc in Supply Chain Management & UCD Michael Smurfit & Dublin \\
\hline & MComm in Supply Chain Management (Lean SCM Black Belt) & University College Cork & Cork \\
\hline & Supply Chain Management & University of Limerick & Limerick \\
\hline & \multicolumn{3}{|c|}{ SPAIN } \\
\hline & MSc in SCM & EAE BS-Univ. Politécnica Catalunya & Barcelona \\
\hline & MSc in SCM & EAE BS-Univ. Rey Juan Carlos & Madrid \\
\hline & MSc in International SCM & EAE BS & Online \\
\hline & MSc in Supply Chain Management \& Logistics & OBS BS- Univ. Barcelona & Online \\
\hline & MSc in Operations Management \& innovation & OBS BS- Univ. Barcelona & Online \\
\hline & MSc international in Supply Chain Management & Barcelona Ex. BS- Univ. Murcia & Online \\
\hline & MSC in Terrestrial Transport Eng. \& Logistics & Univ. de Jaen & Jaen \\
\hline & MSc in Port and Logistic Management & Univ. de Cadiz & Cadiz \\
\hline & MSc Logistics \& Supply Chain Management & Univ. Autónoma Barcelona & Barcelona \\
\hline & MSc in Logistics and International Commerce & Univ. Barcelona & Barcelona \\
\hline & MSc in Port Management, Planning \& Intermodal Transport & Univ. Oviedo-Cadiz-Coruña & Madrid \\
\hline & MSc Eng. in Logistics \& Supply Chain Management (MIT) & Zaragoza Logistic Center-MIT & Zaragoza + MIT \\
\hline & MSc Supply Chain Management & Zaragoza Logistic Center-UZ & Zaragoza \\
\hline & MSc in Logistics and Supply Chain Management & IMF BS-Univ- Camilo José Cela & Online \\
\hline & MBA in Transports and Logistics & IMF BS-Univ- Camilo José Cela & Madrid \\
\hline & MSc in international logistics and SCM & EUDE BS- Univ. Rey Juan Carlos & Online \\
\hline & MSc in international logistics and SCM + MBA & EUDE BS-Univ. Rey Juan Carlos & Madrid \\
\hline & MSc in Operation Management and Logistics & Barcelona Executive BS & Online \\
\hline & MSc integral logistics: operations and SCM & INSA BS & Barcelona \\
\hline & MSc in Port Management and Intermodal Transportation & ICADE BS + Univ. Pontificia Comillas & Valencia \\
\hline
\end{tabular}


APPENDIX B.

Supply Chain Management skill areas, items included in the questionnaire and main sources

\begin{tabular}{|c|c|c|c|c|c|}
\hline \multicolumn{2}{|c|}{ Generic Skills in SCM } & \multicolumn{2}{|c|}{ Functional Skills in SCM } & \multicolumn{2}{|c|}{ Analytical Skills in SCM } \\
\hline Included items & Main sources & Included items & Main sources & Included items & Main sources \\
\hline G1.Knowledge of cultural differences & \multirow{19}{*}{$\begin{array}{l}\text { Gammelgaard and Larson } \\
\text { (2001), Prajogo and Sohal } \\
\text { (2013), Rahman and Qing } \\
\text { (2014), Farrell and } \\
\text { Wagner (2014), Wong et } \\
\text { al. (2014), Dubey and } \\
\text { Gunasekaran (2015) }\end{array}$} & F1.Transport management & \multirow{19}{*}{$\begin{array}{l}\text { Murphy and Poist (1991, } \\
\text { 2007), Rahman and Qing } \\
\text { (2014), Dubey and } \\
\text { Gunasekaran (2015) }\end{array}$} & A1.Knowledge of the latest technologies & \\
\hline G2.Ability to see the "big picture" & & F2.Inventory management & & A2.Quantitative modelling skills & \\
\hline G3.Comfort with change & & F3.Demand forecasting & & A3.Information technology skills & \\
\hline G4.Conflict management & & F4. Warehousing management & & A4.Spreadsheet / Excel skills & Gammelgaard and Larson \\
\hline G5.People skills & & F5.Distribution requirement planning & & A5.Database skills & (2013), Rahman and Qing \\
\hline G6.Knowledge of the industry & & F6.Order processing & & A6.Statistical skills & $\begin{array}{c}\text { (2014), Dubey and } \\
\text { Gunasekaran (2015) }\end{array}$ \\
\hline G7.Negotiating skills & & F7.Transportation regulation & & A7.ERP Integration-info flow internally & \\
\hline G8.Influencing skills & & F8.Purchasing & & A8.ERP/EDI Integration-info flow externally & \\
\hline G9.Teamwork / Team-orientation & & F9.Facilities location & & A9.Software knowledge & \\
\hline G10.Ability to prioritize & & \multirow{2}{*}{$\begin{array}{l}\text { F10.Materials handling } \\
\text { F11.Master Production Scheduling }\end{array}$} & & \multicolumn{2}{|c|}{$\begin{aligned} \text { EFA result: Retain } 7 \text { items out of } 9 \text { in } 2 \text { factors (66\% variance). Cronbach } \alpha \\
=0.807\end{aligned}$} \\
\hline G11.Time management & & & & \multicolumn{2}{|c|}{ Environmental Skills in SCM } \\
\hline G12.Oral communication & & \multirow{2}{*}{$\begin{array}{l}\text { F12.Project management } \\
\text { F13.Benchmarking ability }\end{array}$} & & E1.Return goods handling & \\
\hline $\begin{array}{l}\text { G13.Written communication/report } \\
\text { writing skills }\end{array}$ & & & & E2.ISO 14000 Standards & \\
\hline $\begin{array}{l}\text { G14.Cross-functional coordination } \\
\text { ability }\end{array}$ & & F14.Supply chain costing skills & & E3.Salvage and scrap disposal & $\begin{array}{l}\text { Prajogo and Sohal (2013), } \\
\text { Rahman and Qing (2014) }\end{array}$ \\
\hline G15.Customer awareness & & F15.Quality management & & E4.Reverse logistics & \\
\hline G16.Self-development & & F16.Logistics planning & & E5.Knowledge of environmental issues & \\
\hline G17.Leadership skills & & F17.MRP & & \multicolumn{2}{|c|}{$\begin{array}{c}\text { EFA result: Retain all } 5 \text { items in } 2 \text { factors (71\% variance). } \\
\text { Cronbach } \alpha=0.827\end{array}$} \\
\hline G18.Critical thinking skills & & F18.Lean / JIT & & \multicolumn{2}{|c|}{ Security Skills in SCM } \\
\hline $\begin{array}{l}\text { G19.Problem solving skills } \\
\text { G20.Presentation skills } \\
\text { G21.Managing stress }\end{array}$ & & $\begin{array}{l}\text { F19.Service management } \\
\text { F20.Supply Chain strategy }\end{array}$ & & \multirow{2}{*}{\begin{tabular}{|l} 
S1.Customs/trade partnership against terrorism \\
S2.CTPAT knowledge \\
S3.Container Security Initiatives knowledge \\
S4.24-h Manifest rules knowledge
\end{tabular}} & $\begin{array}{l}\text { Hintsa et al. (2009), Voss } \\
\text { and Williams (2013), } \\
\text { Yang and Wei (2013) }\end{array}$ \\
\hline \multirow{2}{*}{\multicolumn{2}{|c|}{$\begin{array}{c}\text { EFA result: Retain } 17 \text { out of } 21 \text { items in } 3 \text { factors (65\% variance). } \\
\text { Cronbach } \alpha=0.928\end{array}$}} & \multirow{2}{*}{\multicolumn{2}{|c|}{$\begin{array}{l}\text { EFA result: Retain } 17 \text { out of } 20 \text { items in } 4 \text { factors (70\% variance). } \\
\text { Cronbach } \alpha=0.915\end{array}$}} & & \\
\hline & & & & $\begin{array}{r}\text { EFA result: Retain all } 4 \text { items in } 2 \text { fact } \\
\text { Cronbach } \alpha=0.873\end{array}$ & rs (68\% variance). \\
\hline
\end{tabular}

Items in bold were eliminated after Exploratory Factor Analysis (EFA). Source: Own elaboration. 
